\title{
AKU “APOTEKER CILIK” DI SEKOLAH DASAR NEGERI 4 SUNGAI BESAR BANJARBARU KALIMANTAN SELATAN
}

\author{
Nurul Mardiati, Lisa Andina, Helmina Wati, \\ Yaumi Musfirah, dan Depy Oktapian Akbar \\ Sekolah Tinggi Ilmu Kesehatan Borneo Lestari Banjarbaru, Kalimantan Selatan
}

\begin{abstract}
Abstrak: Dewasa ini, pembinaan program pendidikan kesehatan dan pelayanan kesehatan di usia sekolah terutama di tingkat sekolah dasar sudah mulai berkembang. Untuk menyempurnakan pembinaan pendidikan kesehatan dan pelayanan tersebut perlu juga adanya apoteker cilik yang nantinya bisa saling berdampingan. "Aku Apoteker Cilik" merupakan suatu kegiatan pengenalan profesi kefarmasian kepada anak-anak usia dini sehingga dapat mengenal dan menumbuhkan minat kepada profesi kefarmasian. Kegiatan pengabdian masyarakat ini dilaksanakan di Sekolah Dasar Negeri 4 Sungai Besar, Banjarbaru, Kalimantan Selatan. Kegiatan Pengabdian Masyarakat ini dilakukan dengan pengisian materi seputar pengenalan sosok profesi Apoteker serta tugasnya. Media yang digunakan adalah LCD, banner, alat peraga apoteker, dan perangkat aplikasi kefarmasian. Setelah pengisian materi, dilakukan juga games dan kegiatan aplikasi kefarmasian untuk mengetahui pemahaman peserta didik. Peserta didik paling aktif dijadikan sebagai maskot apoteker cilik. Kegiatan telah dilaksanakan pada hari Jumat/02 September 2016 pada pukul 08.00 WITA. Rundown kegiatan diawali dialog pengantar dengan menggunakan alat peraga profesi kesehatan dokter dan apoteker. Selanjutnya dilakukan penyajian video "Tahu Nggak Sih?" seputar sosok dan tugas apoteker. Disesi berikutnya dilakukan penyampaian materi terkait dunia kefarmasian dan sosok \& tugas apoteker serta games. Dilanjutkan penyajian video "Peracikan Obat" dan kegiatan aplikasi kefarmasian. Disesi akhir dilakukan pemilihan peserta didik paling aktif sebagai maskot apoteker cilik.
\end{abstract}

Kata Kunci: Apoteker, Apoteker cilik, Banjarbaru

\section{PENDAHULUAN}

Dewasa ini, pembinaan program pendidikan kesehatan dan pelayanan kesehatan di usia sekolah terutama di tingkat sekolah dasar sudah mulai berkembang, contohnya sudah banyak dokter kecil yang dimiliki oleh sekolahsekolah dasar. Hal tersebut seiring dengan kampanye yang telah dilakukan $W H O$ Global School Health Initiative mulai tahun 1995 dalam usaha untuk memobilisasi dan memperkuat kegiatan promosi kesehatan baik di tingkat lokal, nasional, regional maupun global. Promosi kesehatan yang di selenggarakan oleh sekolah-sekolah di Indonesia adalah implementasi kebijakan sekolah sehat yang diperkenalkan oleh WHO pada tahun 1995 (Desai dkk., 2005). Untuk menyempurnakan pembinaan pendidikan kesehatan dan pelayanan tersebut perlu juga adanya apoteker cilik yang nantinya bisa berdampingan dengan dokter kecil sehingga dapat menciptakan suasana sehat di lingkungan sekolah maupun dilingkungan rumah. Peran dari apoteker cilik ini berguna mengenalkan kegiatan kefarmasian kepada anak-anak usia dini.

“Aku Apoteker Cilik" merupakan suatu kegiatan pengenalan profesi kefarmasian kepada anak-anak usia dini sehingga dapat mengenal dan menumbuhkan minat kepada profesi kefarmasian. Kegiatan pengabdian 
masyarakat ini dilaksanakan di Sekolah Dasar Negeri 4 Sungai Besar, Banjarbaru, Kalimantan Selatan. Program ini diharapkan menjadi media untuk memperkenalkan profesi apoteker kepada anak sejak usia dini, yaitu sejak di bangku sekolah dasar. Kegiatan ini juga melibatkan mahasiswa Sekolah Tinggi Farmasi Borneo Lestari dengan tujuan untuk mengenalkan mahasiswa kepada masyarakat, sehingga diharapkan dapat merangsang sisi afektif dan psikomotorik mahasiswa dengan adanya interaksi langsung dengan masyarakat.

Tujuan dari kegiatan ini yaitu: 1) Agar peserta didik mengetahui profesi Apoteker serta tugasnya sehingga dapat mengenal dan menumbuhkan minat kepada profesi tersebut

2) Membantu sosialisasi dini apa sajakah tenaga medis yang bertanggung jawab di bidang kesehatan saat ini.

\section{METODE PELAKSANAAN}

\section{KEGIATAN}

Khalayak Sasaran

Khalayak sasaran dalam kegiatan ini adalah seluruh siswa kelas 3 Sekolah Dasar Negeri 4 Sungai Besar, Banjarbaru, Kalimantan Selatan. Pemilihan ini dilakukan karena kelas 4, 5, dan 6 lebih disibukkan untuk persiapan Ujian Nasional. Sedangkan kelas 1 dan 2 masih terlalu kecil. Peserta yang mengikuti Aku
“Apoteker Cilik" ini adalah sejumlah 31 anak.

Metode yang Digunakan \& Materi Kegiatan

Metode pelaksanaan pengabdian dilakukan dengan mempresentasikan materi seputar pengenalan sosok profesi Apoteker serta tugasnya, termasuk sosialisasi dini apa sajakah tenaga medis yang bertanggung jawab di bidang kesehatan saat ini. Media yang digunakan adalah LCD, banner, alat peraga apoteker, dan perangkat aplikasi kefarmasian. Setelah presentasi pengisian materi, dilakukan juga games dan kegiatan aplikasi kefarmasian untuk mengetahui pemahaman peserta didik tentang sosok seorang apoteker serta tugasnya. Peserta didik yang terlihat paling aktif sepanjang pelaksanaan program selanjutnya dijadikan sebagai maskot apoteker cilik.

Evaluasi Kegiatan

Dalam kegiatan ini dilakukan pula proses monitoring dan evaluasi dengan indikator keberhasilan sebagai berikut:

1. Selama penyampaian materi, peserta didik tidak hanya mendengarkan materi yang dipresentasikan tim Sekolah Tinggi Ilmu Kesehatan Borneo Lestari tetapi akan membuat berbagai umpan balik sehingga peserta dapat secara aktif bertanya. Demikian pula saat sesi games. 
2. Selama kegiatan aplikasi kefarmasian, peserta yang telah mendapatkan materi diminta untuk memperagakan simulasi proses peracikan obat.

\section{HASIL DAN PEMBAHASAN}

Dalam bingkai pelaksanan

Tridharma Perguruan Tinggi, Kegiatan Pengabdian Masyarakat ini dilaksanakan dengan tujuan pertama agar peserta didik mengetahui profesi Apoteker serta tugasnya sehingga dapat mengenal dan menumbuhkan minat kepada profesi tersebut. Kedua, membantu sosialisasi dini apa sajakah tenaga medis yang bertanggung jawab di bidang kesehatan saat ini.

Kegiatan telah dilaksanakan sesuai dengan yang telah dijadwalkan tim pengusul yaitu pada hari Jumat/02 September 2016 pada pukul 08.00-10.00 WITA di Sekolah Dasar Negeri 4 Sungai Besar Banjarbaru. Dalam pelaksanaannya, tim utama kegiatan ini terdiri atas tiga orang dosen, dengan teknis dan mengikut sertakan para mahasiswa Sekolah Tinggi Farmasi Borneo Lestari Banjarbaru baik dari program studi S-1 Farmasi maupun DIII yang telah melalui seleksi open recruitment kepanitiaan sebelumnya.

Rundown kegiatan diawali dialog pengantar dengan menggunakan alat peraga (boneka tangan) profesi kesehatan dokter dan apoteker, disampaikan kepada para peserta bahwasanya keduanya merupakan profesi di bidang kesehatan dan sama-sama mengusahakan kesehatan pasien. Tugas dokter mendiagnosa penyakit, sedangkan apoteker yang meresepkan obat. Keduanya sangat penting untuk berkolaborasi sehingga pemberian obat kepada pasien dapat menjadi lebih tepat dan efektif.
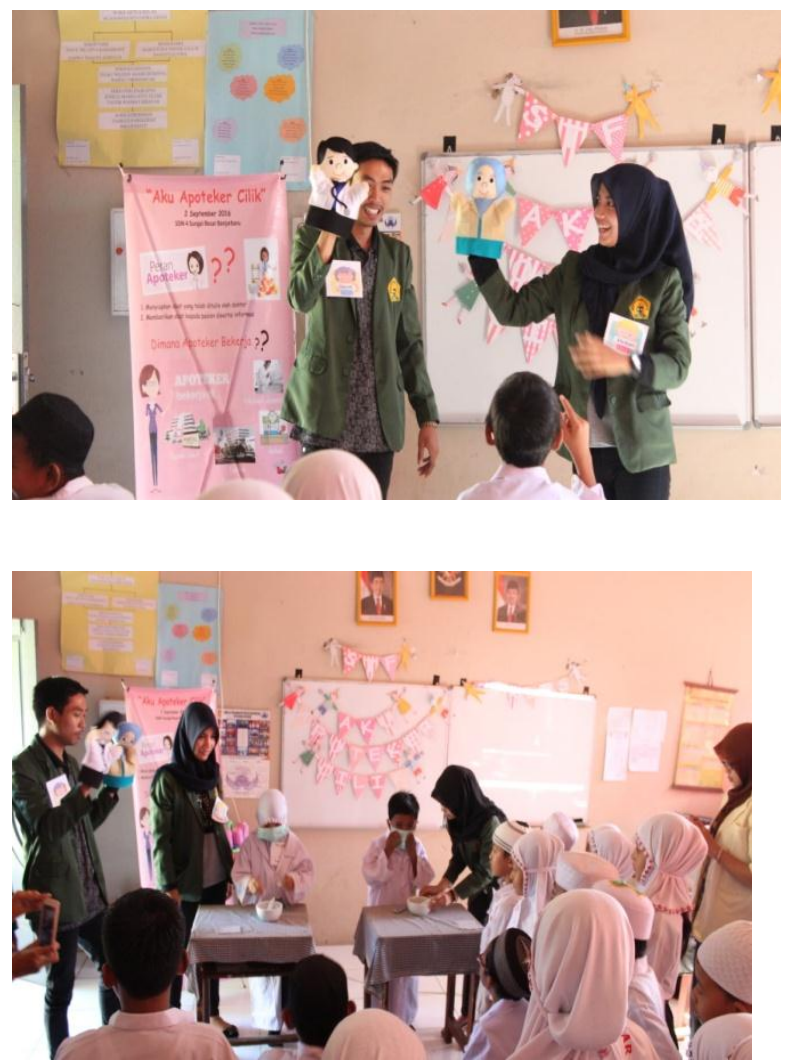

Gambar 1. Penyampaian dialog pengantar Gambar 2. Sesi praktek peracikan obat seputar profesi kesehatan dokter dan apoteker 

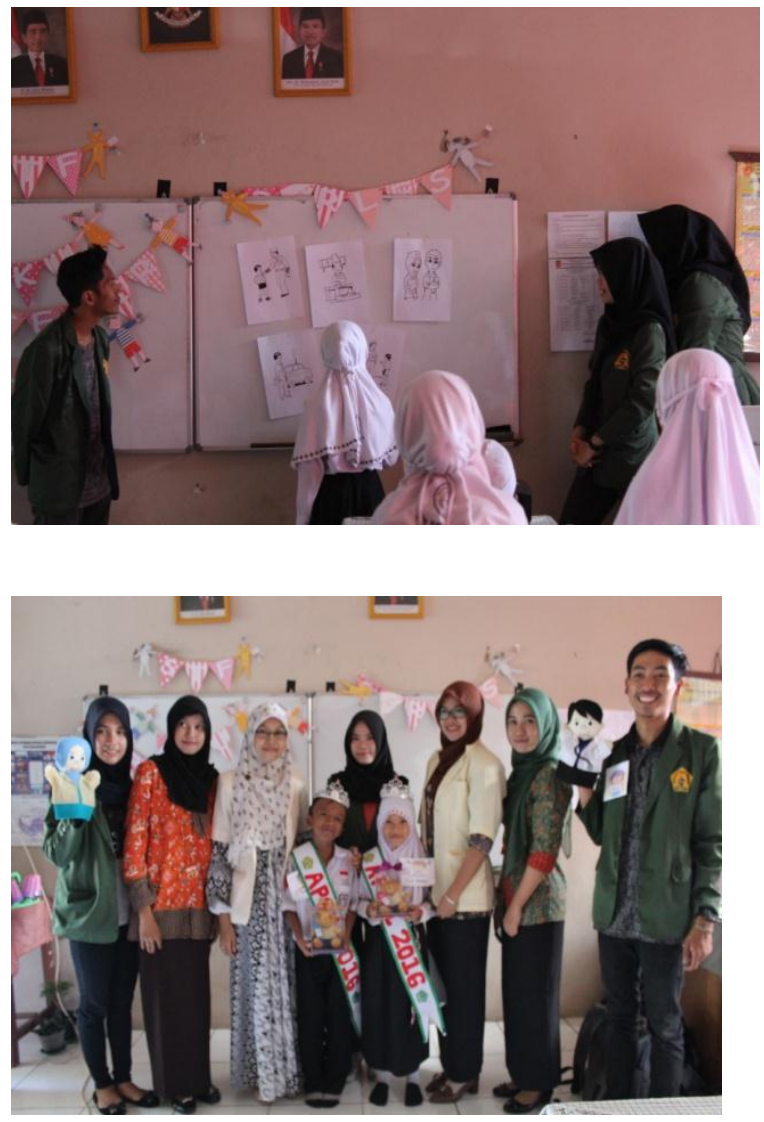

Gambar 3. Games bersama peserta didik Gambar 4. Pemilihan maskot apoteker cilik

Sesi tersebut diatas, sudah mulai berhasil membuat para peserta didik sedemikian tertarik dengan kegiatan ini. Ketertarikan dan antusiasme para peserta didik nampak semakin besar saat tim presentator menyajikan video "Tahu Nggak Sih?" seputar sosok dan tugas apoteker. Video memuat komentar para siswa di Sekolah Dasar Negeri 4 Sungai Besar Banjarbaru sendiri seputar sosok dan tugas apoteker. Sebagian besar komentar para siswa menunjukkan kekurangtahuan tentang sosok dan tugas apoteker, misalnya saja saat ditanyakan "Tahu Nggak Apoteker?", sebagian besar menjawab "Tidak tahu". Begitu juga saat ditanyakan "Siapa yang biasanya melayani pembelian obat di apotek?", sebagian besar justru menjawab "Dokter" dan bukan Apoteker.

Selanjutnya

dilakukan penyampaian materi terkait dunia kefarmasian secara umum dan sosok serta tugas apoteker. Penyampaian materi yang masih menggunakan media alat peraga (boneka tangan) profesi kesehatan dokter dan apoteker berhasil terus mempertahankan ketertarikan dan antusiasme para peserta didik. Selama penyampaian materi sesekali dilakukan tanya-jawab dengan para peserta didik, pun tergambar ketertarikan dan antusiasme perserta didik yang sangat tinggi. Demikian pula pada saat sesi games yang juga masih seputar sosok dan tugas seorang apoteker guna mengetahui sejauh mana pemahaman para peserta didik.

Setelah sesi penyampaian materi, tim presentator kembali menyajikan video "Peracikan Obat". Selanjutnya, dilakukan kegiatan aplikasi kefarmasian. Pada sesi ini, beberapa peserta didik didampingi mahasiswa mempraktikkan peracikan obat. Peserta didik dikenalkan dengan perangkat-perangkat dan tahapan-tahapan dalam proses peracikan obat. Seluruh sesi pada kegiatan ini diakhiri dengan 
pemilihan peserta didik paling aktif sepanjang pelaksanaan kegiatan sebagai maskot apoteker cilik dan penyerahan kenang-kenangan untuk Sekolah Dasar Negeri 4 Sungai Besar Banjarbaru.

\section{KESIMPULAN}

Kesimpulan yang diperoleh yaitu kegiatan ini dapat memberikan pengetahuan dan pemahaman peserta didik tentang profesi Apoteker serta tugasnya. Selain itu, pemahaman terkait profesi tenaga medis dengan bidang tanggung jawabnya masing-masing di bidang kesehatan saat ini.

\section{DAFTAR PUSTAKA}

Desai, C., Girdhar A.O, Shah U.H, 2005, Knowledge and Awareness about Medicines among Primary SchoolChildren in Ahmedabab, India., Regional Health Forum, Volume 9, Number 2:1-8. 